\title{
Terorisme, Radikalisme dan Fundamentalisme
}

\section{Azyumardi Azra}

Guru Besar dan Mantan Rektor/Mantan Direktur Sekolah Pasca-Sarjana Universitas Islam Negeri (UIN) Syarif Hidayatullah

\section{Abstract}

This article argues, terrorist cell germination occurs because of people in the community who don't want to care or even protect terrorists. There are even community members who take them as sons-in-law. No wonder then that they are very hard to find; and once the place where they kissed the authorities, they had already fled to another place that was not known to security officials. Therefore, once again, the collaboration of all levels of society, the government and various related ministries, security forces, mass organizations, and social leadership is absolutely essential in combating terrorism. Terrorism for any reason cannot be justified; and terrorism is one of the most naked forms of crime against humanity.

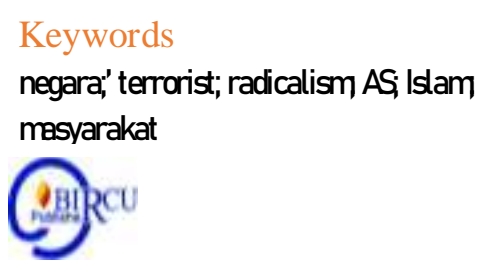

\section{Pendahuluan}

Salah satu tantangan besar yang belakangan ini dihadapi negara-bangsa Indonesia, warga dan ormas arus utama (mainstream) umat beragama di Indonesia-dan juga di banyak tempat lain di muka bumi - adalah peningkatan fundamentalisme, radikalisme dan terorisme. Peristiwa 11 September 2001 di New York dan Washington DC, yang diikuti serangan AS dan sekutunya ke Afghanistan dan kemudian ke Iraq-yang sampai sekarang masih belum terselesaikan-ditambah konflik dan kekerasan yang terus berlanjut antara Israel dan Palestina, menjadi faktor terpenting meningkatnya fundamentalisme, radikalisme dan terorisme yang dilakukan kalangan Muslim tertentu.

Menghadapi radikalisme dan terorisme, ormas arus utama Islam di Indonesia awalnya cenderung bersikap defensif dan apolo-getik. Sikap ini muncul karena pandangan, terorisme yang dila-kukan 'oknum-oknum' Muslim merupakan 'konspirasi' Amerika dan Barat untuk mendiskreditkan dan menyudutkan kaum Muslim dan Islam. Tetapi, sikap ini berubah setelah munculnya berbagai pengungkapan para pelaku terorisme di Indonesia, bahwa aksi teror yang mereka lakukan adalah inisiatif dan tindakan mereka sendiri; bukan direkayasa pihak lain.

Dengan begitu, akhirnya ormas-ormas Islam arus utama lainnya dapat lebih secara tegas mengutuk terorisme sebagai berten-tangan dengan ajaran dan prinsip Islam. Sikap lebih tegas ini, cukup efektif dalam membuat merosotnya 'simpati' dari kalangan Muslim tertentu pada para pelaku aksi terorisme di negara ini, sehingga Polri dan Pengadilan dapat melakukan tindakan seperlunya dalam memberantas terorisme tanpa dibayangi kekhawatiran pada 'Muslim backlash'. Mengingat kompleksitas fundamentalisme, radikalisme dan terorisme perlu state of the art penanganannya. 


\section{Kajian Pustaka}

\section{Akar Terorisme Kontemporer}

Banyak kondisi penyebab tumbuhnya radikalisme dan terorisme di kalangan umat beragama manapun. Tetapi dalam konteks Muslim, salah satu faktor terpenting adalah kegagalan banyak negara Dunia Islam dalam pembangunan politik dan ekonomi yang viabel untuk memperbaiki kesejahteraan warga. Dengan kata lain, para penguasa di banyak negara Muslim gagal memenuhi janji kemajuan politik dan kesejahteraan ekonomi rakyat. Pada gilirannya, kondisi seperti itu mendorong tidak hanya kekecewaan, apatisme dan alineasi, tapi juga perlawanan terhadap rejim penguasa Muslim dan sekaligus Dunia Barat pendukung mereka.

Yang terakhir ini juga memunculkan apa yang dapat disebut 'structural antiWesternism/Americanism', sikap anti Barat/ Amerika yang terwujud secara struktural, yang mengakar sangat kuat di kalangan kaum Muslimin. Menurut konsep ini, kema-rahan kalangan Muslim terhadap Barat/Amerika semula ber-akar dalam struktur sosial, ekonomi dan politik sebagian negara Muslim sendiri dan oposisi dan perlawanan terhadap kebijakan Amerika memberikan isi dan kesempatan bagi aktualisasi ekspresi kemarahan tersebut.

Perkembangan dan gejala itu selanjutnya beramalgamasi dalam proses sosio-relijius masyarakat Muslim sendiri seperti mening-katnya semangat 'Kebangkitan Islam'. Peningkatan ini bagi seba-gian kalangan Muslim membawa mereka ke dalam pemahaman dan pengamalan Islam kian ketat, memunculkan 'fundamental-isme'-secara harfiah berpegang hanya kepada fundamentals of religions (usuliyyah). Jika fundamentalisme terus menjadi kian ketat, tahap selanjutnya adalah radikalisme yang dapat berujung pada terorisme.

Dengan perkembangan tersebut, terdapat kalangan Muslim yang kian memperketat 'batas-batas' yang membedakan atau memisahkan mereka dari kaum Muslimin lain dan Barat. Dalam perkembangan lebih lanjut, peristiwa-peristiwa seperti Revolusi Iran 1979, Perang Afghanistan melawan rejim Uni Soviet, Perang Teluk 1991, Peristiwa 11 September 2001, 'perang Amerika dan sekutu di bawah pimpinan Presiden George W Bush terhadap teror', ketidakadilan terhadap bangsa Palestina terbukti juga menjadi katalisator bagi radikalisme dan terorisme.

Dalam semangat bernyala-nyala, para pemimpin-yang juga mencakup ulamagerakan fundamentalis dan radikal mem-bangun justifikasi keagamaan bagi fundamentalisme, radikal-isme dan terorisme. Maka, jihad dengan segera diidentikkan sebagai perang suci melawan AS dan kekuatan Barat lain. Dengan tidak lagi mempertimbangkan doktrin jihad yang demikian rinci beserta syarat-syaratnya yang ketat seperti dirumuskan para pemikir fiqh siyasah klasik, pemikir dan aktivis kelompok fundamentalis dan radikalis mengabsyahkan tindakan bunuh diri, misalnya melalui suicide bombings. Para pelaku pemboman bunuh diri beserta keluarga terdekat mereka diimingimingi 'janji' langsung masuk surga dan bertemu dengan bidadari-bidadari.

Media massa juga turut bertanggungjawab dalam menyebarkan konsep jihad yang keliru, misalnya melalui penggunaan istilah 'jihadists' yang kian meluas belakangan ini untuk menyebut orang-orang Islam yang terlibat dalam terorisme. Padahal jelas, tindakan teror mereka, yang mengakibatkan tewasnya banyak 'innocent people' bukanlah 'jihad' dalam arti sesungguhnya. Penggunaan istilah jihad seperti itu selain merupakan distorsi dan tidak sesuai ajaran Islam yang benar, sekaligus juga merupa-kan stigmatisasi terhadap Islam dan Muslim.

Selain itu, media massa-khususnya TV-juga ikut bertang-gungjawab dalam penyebaran citra 'glorifikasi' terhadap para pelaku teror. Hal ini terjadi melalui laporan tidak berimbang, yang cenderung lebih banyak menyajikan perspektif para pelaku teror dan para 
pendukung mereka. Juga terjadi glorifikasi dalam prosesi eksekusi para pelaku teror yang sebelumnya telah dija-tuhi hukuman mati oleh pengadilan.

Demikian, sekali lagi proses perkembangan fundamentalisme, radikalisme, dan terorisme di kalangan masyarakat Muslim tidak sederhana. Sumbernya terdapat secara internal di dalam masalah politik di negara-negara Muslim sendiri, penafsiran konsep jihad yang keliru, dan juga karena adanya faktor eksternal yang memicunya. Karena itu, penyelesaiannya memer-lukan pembenahan-seperti perubahan kebijakan politik-di wilayah kaum Muslimin sendiri, sosialisasi pemahaman yang benar tentang jihad, dan sekaligus perubahan eksternal, yakni penyelesaian masalah di dunia Muslim yang melibatkan Ame-rika Serikat dan Dunia Barat umumnya.

Lebih jauh, masih menyangkut akar-akar terorisme, dalam peringatan setahun setelah 'Teror Madrid' (11 Maret 2004), Club de Madrid menggelar 'International Summit on Democracy, Terrorism, and Security' (8-11 Maret 2005). Dibuka Raja dan Perdana Menteri Spanyol, yang kemudian ditutup Sekjen PBB Kofi Annan. KTT menghadirkan banyak kepala negara dan kepala pemerintahan dari berbagai dunia ditambah para sarjana, dan pakar paling terkemuka dalam ketiga bidang tadi, demo-krasi, terorisme dan keamanan. Hadir sebagai satu-satunya orang Indonesia, sepanjang pengetahuan saya, inilah pertemuan ilmiah dan akademis - yang tentu juga mengandung makna politis - terbesar tentang ketiga tema tadi. Berbeda dengan perte-muan-pertemuan lain dengan tema sama, KTT Madrid diselenggarakan dengan pengamanan sangat ketat.

Kelompok kerja para ahli-termasuk saya sendiri-yang telah berdiskusi melalui internet berbulan-bulan sebelum KTT, menghasilkan sejumlah kesepakatan penting. Pertama, bahwa dewasa ini tidak ada negara yang kebal dan pasti terhindar dari terorisme yang definisinya disepakati sebagai 'tindakan keke-rasan tanpa pandang bulu (indiscriminate) yang ditujukan untuk menciptakan ketakutan luarbiasa di tengah masyarakat secara keseluruhan'. Akar-akar terorisme juga sangat kompleks, yang merupakan gabungan dari berbagai faktor, sejak dari ketidak-puasan politik domestik dan internasional, kemiskinan, keterbe-lakangan pendidikan, penafsiran literal dan sepotong-sepotong atas agama, alienasi dan ketercerabutan budaya, dan banyak lagi.

Khusus tentang akar keagamaan terorisme, Kelompok Kerja yang dipimpin Professor Mark Juergensmeyer dari UC Santa Barbara, AS, menyepakati, agama per se jarang atau hampir tidak pernah menjadi satu-satunya penyebab terorisme. Yang sering terjadi, terorisme memiliki akar dalam faktor ekonomi, politik, sosial dan budaya yang bercampur baur satu sama lain, yang kemudian dijustifikasi penafsiran literal dan ketat atas agama; atau bahkan dengan sengaja melakukan penafsiran menyesat-kan-yang tidak sesuai dengan penafsiran yang disepakati para penafsir agama otoritatif dan diakui. Penafsiran seperti ini turut menyumbang terciptanya culture of violence di kalangan kelom-pok keagamaan yang menolak 'kompromi' dengan pihak-pihak lain yang mereka pandang sudah 'sesat' (Muslim dan non-Muslim); dan mereka memegang perspektif tentang urgensi 'perang kosmik' yang harus mereka lakukan.

\section{Pembahasan}

\subsection{Densus 88 dan Circle of Terrorism}

Memandang akar-akar terorisme yang begitu kompleks, penanganannya juga mesti multi-facetted, multi-track dan kompre-hensif. Respon militer dan keamanan saja tidak akan mampu menangani terorisme. Sebaliknya, justru dapat kontra-produktif dan menciptakan ekses-ekses yang dapat menciptakan 'lingkar-an terorisme' (circle of terrorism) yang sulit diakhiri. 
Lebih jauh, terorisme tidak dapat dibasmi dengan tindakan unilateral; sebaliknya harus melalui kerjasama multi-lateral, khususnya melalui lembaga-lembaga internasional, terutama PBB. Unilateralisme negara pada tingkat internasional, hanya menumbuhkan ketegangan internasional - di antara berbagai negara dan sekaligus di antara masyarakat-masyarakat dunia.

Pada tingkat domestik, meski bukan satu-satunya obat mujarab, demokrasi dipandang sebagai alternatif untuk mengurangi jika tidak dapat menghilangkan terorisme secara keseluruhan. Penguatan demokrasi mestilah sejalan dengan pemberdayaan aparat dan tatanan hukum dengan tetap menghormati HAM; penguatan civil society dan pemberian ruang partisipasi dan dialog lebih besar. Dengan begitu socio-religious and political discontents yang dapat berujung pada terorisme dapat diakomo-dasi dan disalurkan dengan penuh keadaban.

Di atas semua itu, jelas peran aparat kepolisian, dalam konteks Indonesia berada terutama di tangan Densus 88 yang tugas pokoknya adalah memberantas terorisme. Adanya detasemen khusus ini terasa diperlukan, karena penanganan terorisme yang termasuk ke dalam extra-ordinary crimes against humanity tidak bisa ditangani dengan pendekatan dan cara konvensional.

Banyak kalangan internasional dan pengamat security menilai Densus 88 sangat berhasil dalam pemberantasan terorisme. Mereka berhasil menangkap dan/atau menewaskan para pimpinan organisasi atau kelompok dan sel terorisme sehingga potensi terorisme di Indonesia menjadi kian terpencar dan terserak. Di balik keberhasilan itu, jelas masih terdapat sel-sel teroris yang bergerak di bawah tanah, melakukan berbagai cara untuk dapat melakukan aksi teror mereka.

Keberhasilan Densus 88 terkait dengan pendekatan tidak konvensional yang dilakukannya. Pendekatan yang sering dikri-tik pihak asing itu misalnya adalah 'mengakrabi' para terduga, tersangka, dan terpidana teroris. Melalui 'keakraban' personal, aparat Densus 88 selain dapat menggali berbagai informasi penting, sekaligus 'menyadarkan' mereka. Selain itu kalangan Densus 88 juga memberikan semacam bantuan kesejahteraan untuk anak atau keluarga sebagian mereka.

Tetapi aksi Densus 88 juga bukan tidak melibatkan cara yang tidak dapat diterima masyarakat umumnya, seperti penewasan banyak terduga, bukan dengan penangkapan hiduphidup. Juga terlihat adanya indikasi tindakan kekerasan, brutalitas dan humiliation yang jelas melanggar HAM. Tindakan out of control ini dapat memperbesar dendam dan tekad sel-sel teroris yang masih eksis, yang bisa menimbulkan circle of violence tidak ber-ujung.

Karena itu sangat penting bagi Densus 88 dalam pemberantasan terorisme tetap terukur; tidak melakukan brutalitas dan pelang-garan HAM. Masyarakat sipil juga perlu mengawasi kiprah Densus 88, sehingga tidak tergelincir ke dalam tindakan sewenang-wenang.

\subsection{Peran Masyarakat}

Berbagai bom bunuh diri sejak 'Bom Bali I' (Oktober 2002) sampai terungkapnya berbagai sel teroris belakangan ini menyentakkan kesadaran kita, bahwa terorisme masih ada di sekitar kita. Negeri kita tidak pernah bebas dari bahaya dan sekaligus kenestapaan akibat aksi terorisme. Meski dalam kurun waktu itu Densus juga telah membongkar berbagai jaringan kelompok teror di berbagai tempat di tanahair, sel-sel terorisme masih aktif, siap sewaktu-waktu menyebarkan kekerasan dan ketakutan ke dalam kehidupan publik.

Jika kepemimpinan kelompok teroris sering dikatakan telah tercerai-berai, bisa dipastikan masih terdapat sel-sel yang sangat boleh jadi terus berkecambah. Kecambah sel teroris boleh jadi menjadi kian canggih dan semakin radikal. Karena sudah mengetahui cara 
kerja aparat kepolisian, mereka mengadopsi cara dan modus baru dalam aksi teror mereka. Dan, sel dan kecambah baru sel teroris ini juga kian sulit dideteksi aparat kepolisian; juga karena boleh jadi mereka adalah orang-orang baru yang belum terdapat dalam daftar kepolisian.

Sementara sel-sel teroris yang 'tersisa' kian mempercanggih modus dan metode terornya, pengamanan untuk mengantisipasi dan mencegah terorisme hampir tidak berubah sejak penga-manan ketat diberlakukan dalam beberapa tahun terakhir ini di hotel-hotel, malmal, gedung publik dan tempat strategis lain-nya. Pemeriksaan nyaris menjadi kerutinan belaka; menjadi business as usual. Hampir semua kita bisa menyaksikan dan mengalami rutinitas pemeriksaan seperti itu, sehingga patut dipertanyakan efektivitasnya. Lagi pula, aparat pengamanan pun tidak bisa terlalu berani melakukan pemeriksaan menye-luruh, karena tak jarang ada resistansi dari mereka yang diperiksa.

Karena itu, pemberantasan terorisme memerlukan kerjasama semua pihak; bukan hanya tanggungjawab aparat keamanan. Menghadapi terorisme tidak bisa dengan saling mencurigai- apalagi dengan mempercayai 'teori konspirasi', bahwa ada pihak tertentu berkomplot merekayasa teror untuk kepentingan politik dan sebagainya. Mencurigai pihak tertentu tanpa bukti yang dapat diuji dan dipertanggungjawabkan hanya berujung pada friksi dan konflik politik dan sosial. Jika ini terjadi, para teroris berhasil mencapai salah satu tujuannya, yaitu konflik di antara berbagai pihak dalam kehidupan berbangsa-bernegara.

\section{Kesimpulan}

Tidak kurang pentingnya, para pemimpin agama dan ormas-ormas berbasis agama (religious-based) mesti pro-aktif dalam menyebarkan ajaran dan prinsip agama yang tidak membenar-kan terorisme dalam bentuk apapun. Jika pihak-pihak ini bersikap pasif, kelompok dan orang pendukung terorisme dapat dengan mudah mempengaruhi dan merekrut calon teroris, yang kemudian menimbulkan gangguan pada kehidupan politik, sosial dan juga keagamaan.

Pada tingkat akar rumput, peran masyarakat dalam pencegahan terorisme juga tidak kalah penting. Memang kian banyak warga yang kian muak dengan terorisme seperti terlihat misalnya dalam penolakan atas pemakaman terduga teroris di kampung mereka. Tetapi juga terlihat, perkecambahan sel teroris juga terjadi karena adanya orang-orang dalam masyarakat yang tidak mau peduli atau bahkan melindungi teroris. Bahkan ada kalangan masyarakat yang mengambil mereka sebagai menantu. Tidak heran kalau kemudian mereka sangat sulit ditemukan; dan begitu tempat mereka tercium aparat, mereka sudah lebih dahulu kabur ke tempat lain yang tidak diketahui aparat kea-manan.

Karena itu, sekali lagi, kerjasama seluruh lapisan masyarakat, pemerintah dengan berbagai kementerian terkait, aparat kea-manan, ormas, dan kepemimpinan sosial sangat mutlak dalam pemberantasan terorisme. Terorisme atas alasan apapun tidak bisa dibenarkan; dan terorisme adalah salah satu bentuk paling telanjang dari kejahatan terhadap kemanusiaan. Bersama-sama bahu membahu memberantas terorisme merupakan usaha mulia untuk melindungi kemanusiaan dan peradaban.

\section{Daftar Pustaka}

Azyumardi Azra dkk, Reformulasi Ajaran Islam Jihad Khilafah Dan Terorisme, Penerbit Mizan, 2019

Azyumardi Azra, Konflik baru antar Peradaban , Penerbit Raja Grafindo Persada, 2002 